\section{$\mathcal{B} \mathcal{T} \mathcal{P} \mathcal{S}$}

Brazilian Transportation

Planning Society
Journal of Transport Literature

Vol. 7, n. 2, pp. 253-267, Apr. 2013

Research Directory
JTL | RELIT

www.transport-literature.org

\title{
Price effects of airline alliances - design and modelling
}

[Efeitos em preços das alianças de companhias aéreas - desenho e modelagem]

\author{
Cayami S. C. Cavalcante*
}

Embraer, Brazil

Submitted 12 Apr 2012; received in revised form 16 Jul 2012; accepted 4 Aug 2012

\begin{abstract}
This paper performs a comparative literature review of different approaches to explain the effects of international airline alliances on fares. Authors develop different models adopting their own simplifications and boundary conditions. In the models effects of cooperative price setting are shown to have positive effects for consumers. With the improvement of services, consumers may be willing to pay a premium, which can outweigh to positive effects of allocative efficiency. In non-cooperative pricing conditions, both airlines and passengers do not reap the full benefits possible from the system. The loss of competition however always results in an increase on fares. By studying the repertoire on airline alliances it is possible to advance a comprehensive view on the subject.
\end{abstract}

Key words: airline; alliances; pricing; price; fare.

\section{Resumo}

Esse trabalho realiza uma análise comparativa da literatura com diferentes abordagens para explicar os efeitos de alianças entre companhias aéreas na precificação das passagens. Autores da literatura usam modelos diferentes adotando suas próprias simplificações e estabelecendo condições de contorno. Nos modelos, a precificação cooperativa mostra ter efeitos positivos para os consumidores. Com a melhoria dos serviços, consumidores podem estar dispostos a pagar um prêmio monetário que pode sobrepujar os efeitos positivos de maior eficiência na alocação de recursos. Em situações de precificação não-cooperativa, tanto as companhias aéreas quanto os passageiros não colhem os benefícios possíveis da aliança. A perda da competição, no entanto, sempre leva a um aumento dos preços. Com uma investigação da literatura a respeito das alianças aéreas, é possível avançar uma visão compreensiva a respeito da temática.

Palavras-Chave: companhias aérea; aliança; precificação; passagem aérea; preço.

*Email: cayami@gmail.com.

\section{Recommended Citation}

Cavalcanti, C. S. C. (2013) Price effects of airline alliances - design and modelling. Journal of Transport Literature, vol. 7, n. 2, pp. 253-267.

- JTL/RELIT is a fully electronic, peer-reviewed, open access, international journal focused on emerging transport markets and published by BPTS - Brazilian Transport Planning Society. Website www.transport-literature.org. ISSN 2238-1031. 


\section{Introduction}

The objective of this paper is to perform a comparative analysis of the existing literature on the theme of airline alliances and the effects on airfares and passenger welfare. Focus is given to the theoretical modeling and analytical solutions encountered attempting to describe findings along with the author's own conclusions.

Airline alliances are strategic agreements in which airlines cooperate to extend networks and create new connections for passengers while enhancing competitive advantages of the companies involved. By coordinating flight schedules, localizing gates within proximity to each other and uniting frequent flier programs, alliances can create benefits for passengers. Most consumers prefer to fly with a large airline which has an extensive international network (Park, 1997). As a response to passenger preferences and the restrictions on international services codified in various bilateral agreements, international airline alliances have expanded rapidly in recent decades.

In the international environment, regulatory barriers exist to protect national airlines from competition from airlines from foreign countries. These so called Liberties of the Air limit the penetration of foreign airlines into a country's market therefore reducing its ability to provide services to international destinations. By forming alliances, international airlines can create a seamless travel experience to passengers on interline codeshare itineraries between countries.

Different scenarios are possible in which codesharing alliances are created. The pricing incentives and competitive effects of a codesharing alliance depend on both the characteristics of the codesharing partners and the presence (or absence) of competition to become a partner (Chen, 2006). Zou et al. (2010) approaches this problem by broadly classifying alliances into two distinct categories: complementary and parallel alliances. In a complementary alliance the participating airline's original networks did not overlap whereas in a parallel alliance the airlines were competitors on some routes. It is shown that price effects are distinct between these two types of alliances. The elimination of double marginalization and an increase in system efficiency through complementary alliances should cause reduction in fares. On the 
other side of the spectrum, parallel alliances occur with loss of competition by default. Results should differ significantly from complementary alliances.

Without differentiating the types of alliances, Brueckner (2000) also demonstrates that the alliance should boost traffic and reduce fares in all routes other than those on which competition occurred originally. Loss of competition causes fares to rise. So he is able to bring out the effects of both complementary and parallel alliances into one framework. This case is closer to what could be expected in most alliance formations.

In 2003, Brueckner extends his work by demonstrating that greater cooperation between airlines in pricing airfares leads to greater benefits for passengers and airlines alike. In a Nash equilibrium, establishment of subfares by each of the alliance partners by ignoring negative impact on demand for interline service and the other airline's profitability ends up with negative effects for both airlines.

Regulators generally are concerned that by granting exemption from prosecution under antitrust laws, a reduction in the competition in the affected markets would cause sharp rises in fares reducing consumer surplus and economic welfare. The analyses studied show that this is not always the case.

This paper is organized in the following way. In the first section, the different methodologies used by the authors are presented. The models and specific conditions used in each paper are described along with a simplified view of the empirical analyses. Findings are briefly described. In the last section a summary of the findings and conclusions reached by each author are put forth for comparison. We will see that although models represent different circumstances under which alliances can be formed, in general conclusions are complementary. Where cooperative pricing occurs, there is gain for airlines and passengers. However, when an alliance is formed by eliminating competition, welfare decreases. 


\section{Theoretical Modeling}

Network models create a simplified illustration of an airline's operations in a specific circumstance of interest to the author. Table 1 shows the models studied in this paper. In any one of these models, each point represents an airport at which the studied airline operates. Notations adopted for airports are capital letters A, B, C and so on. The lines act as routes actually flown by the airline. In the study of airline alliances, more than one airline will operate in the exemplified network. On any given route, more than one airline may be present. Each line color represents a different airline. Additionally, notation denoting the airline is capital letter A followed by a number: A1, A2, A3 and so on. In this paper, various approaches to the problem of airline alliance effects on fare pricing are summarized for comparison. All approaches illustrate the network before and after the alliance is formed in order to analyze the differences occurred.

The paper that presents the most recent findings that is central to this comparative review is "Assessing the Price Effects of Airline Alliances on Complementary Routes", (Zou et al. 2010). In their study, the authors develop their theoretical model using a simple three-node network in which two points belong to a first country and the third point to a second country. Two airlines operate within this network: A1 and A2. Services offered by the airlines do not overlap on any of the routes.

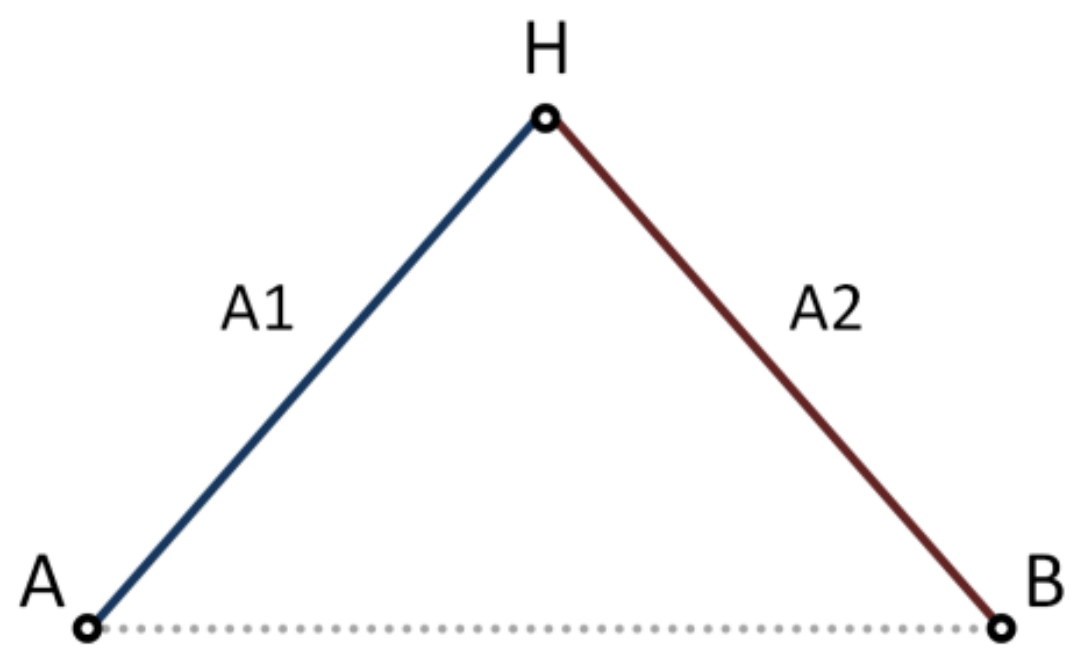


Initially, simplifications are established. Route distances are determined as symmetrical: $\mathrm{AH}$ is the same distance as $\mathrm{BH}$. Passenger demands are also symmetrical meaning for example that demand for travel from point $\mathrm{A}$ to point $\mathrm{B}$ is equal to demand from point $\mathrm{B}$ to point $\mathrm{A}$. These two simplifications greatly reduce the number of variables used to describe the model.

(Zou et al. 2010) chose five different scenarios of interest to study. The first one is the case where there is no alliance between two operators in the AHB system. The second scenario is that in which the two operators jointly set through the ticket fare in a cooperative manner. In the third, costs are reduced by an increase in traffic density. The fourth scenario comprises of an improvement in connecting services stimulating additional demand for travel and increasing passenger willingness to pay for better services. The fifth and final scenario is a combination of the effects of the other three scenarios in which the alliance occurs.

In each one of these scenarios, (Zou et al. 2010) is interested in finding the optimal fares for both airlines. To reach this, it is necessary to describe the profit functions which are simply the difference between revenue and costs. Marginal cost function and demand functions are substituted into the profit functions revealing profit as a function of passenger demand, airfares and marginal cost. By deriving the functions by fare and equaling to zero, the first order conditions are reached. This means that maximal profit occurs at that point where the derivative of profit function is zero. Solving the resulting equations leads to optimal monopolistic fares for both airlines. The second-order conditions for profit maximization establish the valid intervals in which monopolistic fares are valid. This procedure is repeated for each of the five scenarios of interest. The differences between the scenarios are mathematically represented in describing the profit functions. To demonstrate the procedure Zou et al. (2010) used to obtain optimal airfares described above, I have exemplified it below.

Travel demand for air travel is inversely proportional to airfare following the linear function below:

$$
q_{x y}=\alpha-p_{x y}
$$

where $\alpha$ is a constant parameter representing passenger demand while $p_{x y}$ represents the corresponding monopolistic fare. 
Marginal costs are inversely proportional to passenger demand following the linear function below. This shows that there are increasing gains to scale.

$$
c_{(q)}=1-\theta q
$$

The positive parameter $\theta$ reflects the presence and extent of cost reduction as a result of increased traffic density.

The profit function is given by:

$$
\pi=p_{x y} q_{x y}-c_{(q)} q_{x y}
$$

Revenue is simply airfare times demand. Total costs are equal to marginal cost times demand.

By substituting the travel demand and marginal cost functions, we reach the following expression:

$$
\pi=(\theta-1) p_{x y}^{2}+(\alpha+1-2 \alpha \theta) p_{x y}+\theta \alpha^{2}-\alpha
$$

Deriving the profit function in relation to $\mathrm{p}_{\mathrm{xy}}$ and equaling it to zero, we obtain the first order condition for profit maximization. Optimal monopolistic fare is thereby given by the expression:

$$
p_{x y}^{*}=\frac{\alpha-2 \alpha \theta+1}{\theta-1}
$$

The second order condition for profit maximization requires the following inequality condition to hold: $\theta<1$.

Applying this procedure to the five scenarios under study by (Zou et al. 2010), the theoretical investigation shows that the net effect of the airline alliance on fare depends on stimulated demand for improved service in relation to passenger demand and extent of cost reduction as a result of increased traffic density ( $\alpha$ and $\theta$ ). Therefore the net effect of the complementary alliance is unknown a priori. However through an empirical analysis of data obtained from a case, it would be possible to verify the relation between $\alpha$ and $\theta$ and determine whether fares will increase, decrease or remain the same. 
Park (1997) in this study models both complementary and parallel alliances. In a complementary alliance the participating airlines' original networks did not overlap whereas in a parallel alliance the airlines were competitors on some routes. His model uses a similar three-node network as used by (Zou et al. 2010) but in this case, there are three airlines. Airline A1 operates on segments $\mathrm{AH}$ and $\mathrm{BH}$. A2 operates only on $\mathrm{AH}$ and airline 3 operates on segment $\mathrm{BH}$.

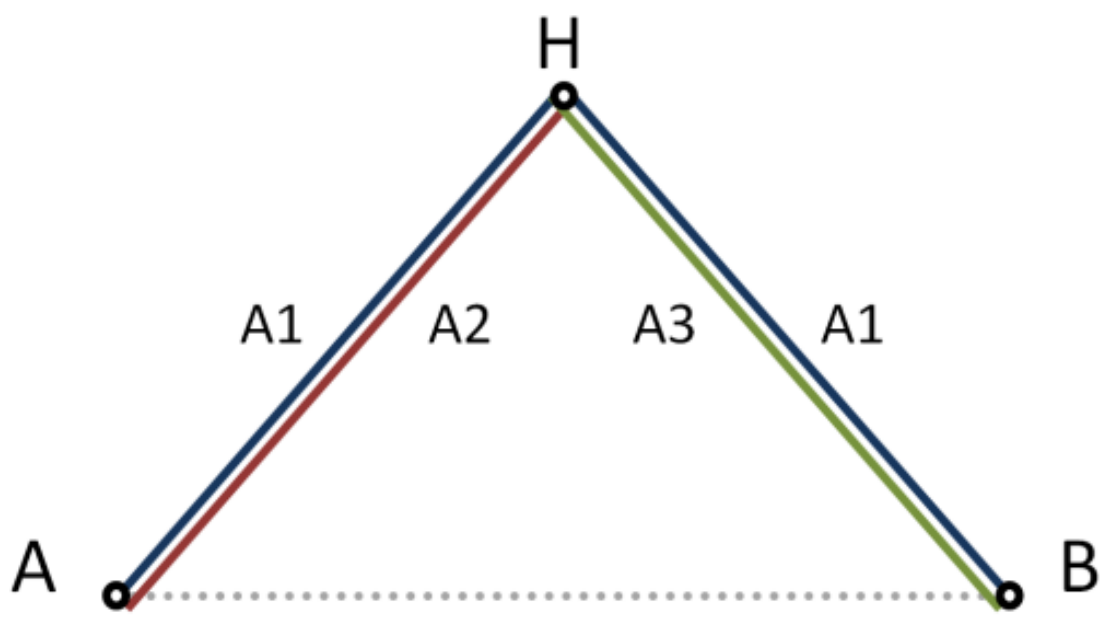

In this study, Park (1997) studied three different scenarios. The first is where no alliance is formed. The second scenario represents a complementary alliance between airlines A2 and A3. The third comprises of a parallel alliance between A1 and A2. Analytical development of this exercise is analogous to the one described above for (Zou et al. 2010). The profit function is described as the difference between revenue and costs. Optimal monopolistic fare occurs at the point where profit is maximized. Complementary alliances are shown to increase welfare. Parallel alliances, on the other hand, reduce competition and generally will decrease consumer surplus.

Yet another author models the problem of airline alliances using the same network illustration. Brueckner (2003) develops the analysis in the same manner as (Zou et al. 2010). Symmetrical conditions are imposed for demand and stage lengths. Another simplification adopted is that the airline's technology presents constant returns to scale. 


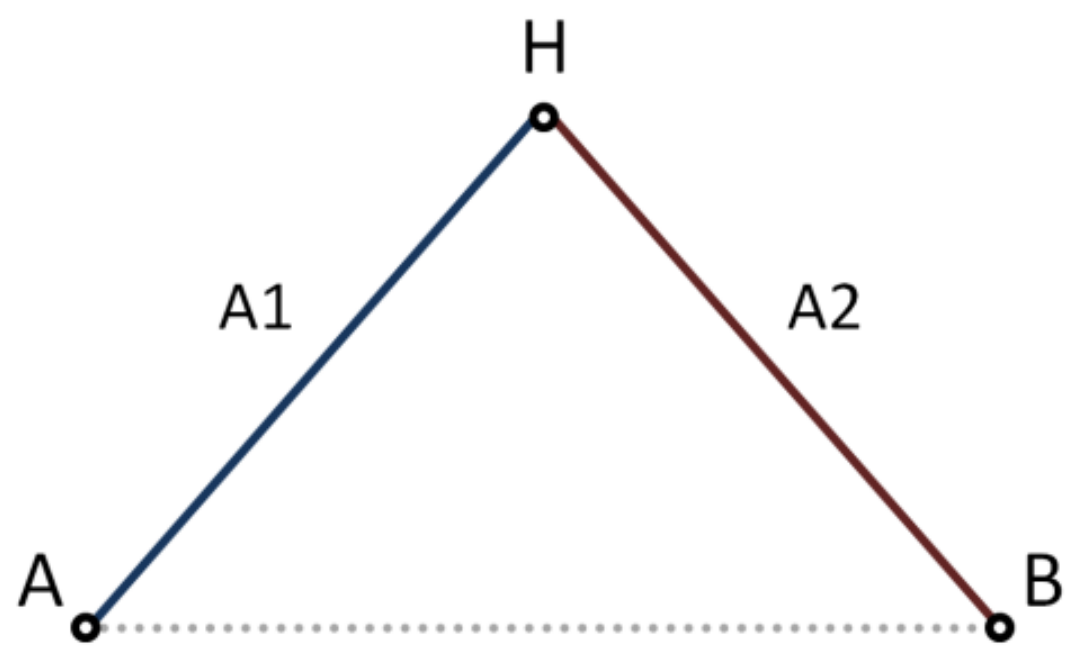

A simplified demonstration of profit maximization for a single airline would be as illustrated below:

$$
\pi=(p-c) D(p)
$$

First order condition leads to:

$$
\frac{D}{D^{\prime}}+p=c
$$

For a given market XY, and substituting inverse-demand slope, the equation may be rewritten as:

$$
q_{x y} \frac{\partial p_{x y}}{\partial q_{x y}}+p_{x y}=c
$$

This condition says that the marginal revenue from an additional passenger in market AC should equal the marginal cost; a typical case of monopolistic profit maximization under the specified simplifications.

For Brueckner (2003) two kinds of fare-setting behaviors are possible: cooperative and noncooperative. Cooperative behavior internalizes externalities so that lower fare is chosen stimulating demand. Non-cooperative behavior means that each airline ignores the negative effects on the other airline's profit from an increase in its own subfare. Although collaborative 
price-setting is only meant to occur in an anti-trust immunity setting, some degree of cooperative price-setting may occur under the guise of a special prorate agreement.

Chen (2006) approaches the problem of airline alliances on fares using a three-node model with three airlines. Interest is in market AC. See his model illustrated below:

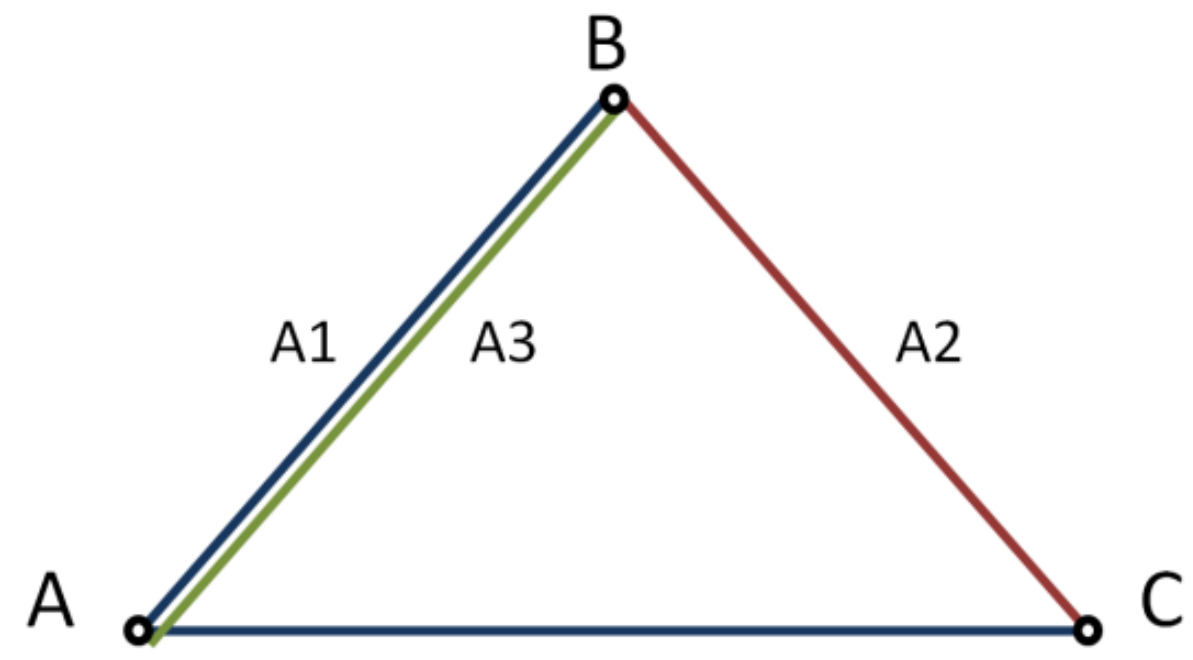

A1

There are four different combinations of market structure and contracting studied:

- Only A3 offers AB and there is no codesharing;

- Only A3 offers AB but there is codesharing between A3 and A2;

- Only A1 offers AB and there is no codesharing;

- Only A1 offers AB but there is codesharing between A1 and A2.

Besides assuming constant returns to scale, Chen (2006) also assumes that prices are strategic complements meaning that demand for a product is increasing in the other product's (substitute's) price. Also demand is more sensitive with respect to its own price change than to price change of the other product.

$$
\frac{\partial q_{i}}{\partial p_{i}}<0<\frac{\partial q_{i}}{\partial p_{j}} \text { and }\left|\frac{\partial q_{i}}{\partial p_{j}}\right|<\left|\frac{\partial q_{i}}{\partial p_{i}}\right| \text {, for } i \neq j
$$


When codesharing occurs, the author imposes that cooperative pricing takes place in order to maximize joint profit. Further development follows the same procedure as described for (Zou et al. 2010) to find optimal price settings. Competitive effects of a codesharing alliance depend mostly on the presence or absence of competition to become a parter. Loss of competition consistently causes fares to increase. However when competition was not present on a determined route beforehand, alliance formation causes fares to decrease even if double marginalization occurs. This is an aspect of post-alliance pricing that the other authors do not discuss.

Brueckner (2001) presents a more complicated six-node network structure divided symmetrically between two airlines.

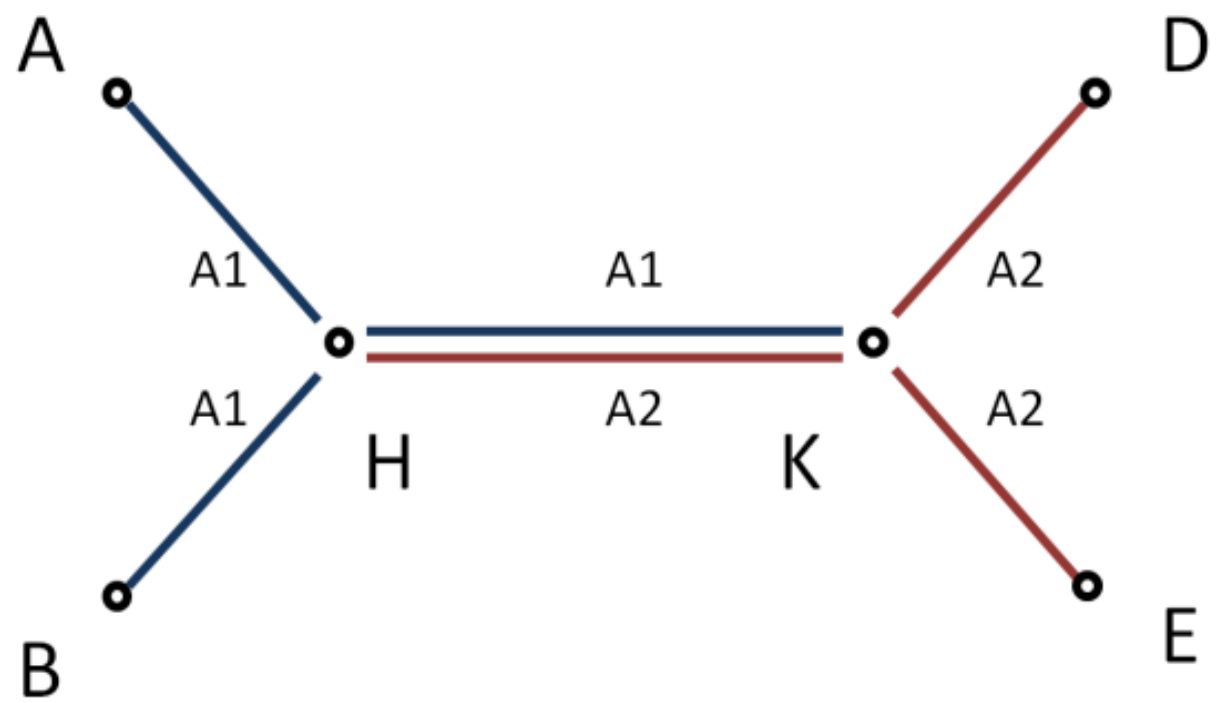

Each airline flies to three different spokes from its own hub. For each airlines two of these routes are domestic and one is an international flight to the other airline's hub. In other words, the only route on which the airlines encounter competition is the interhub market. In the alliance equilibrium, the airlines agree to split the revenue from the interline markets, where each airline carries half of the total traffic. In addition, the airlines collude in the interhub market. In the absence of an alliance, each airline view's the other's fare choice as fixed in Cournot fashion. 


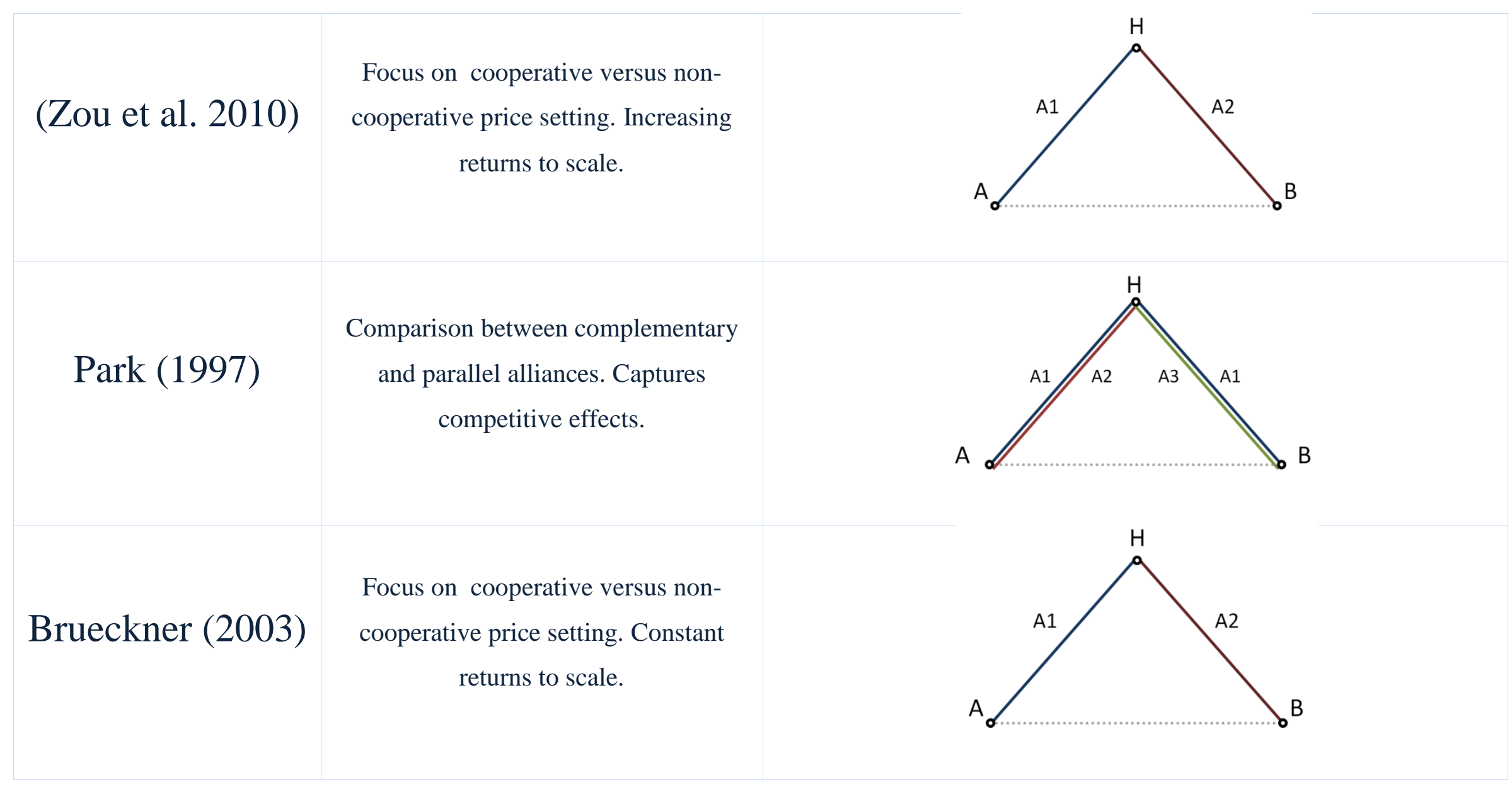

Table 1 - Comparison of Network Models 


\begin{tabular}{|l|l|}
\hline & $\begin{array}{l}\text { Cross elasticity included in the model. } \\
\text { Double-marginalization may still }\end{array}$ \\
decrease fares if no competition existed \\
prior to alliance formation. Captures \\
competitive effects.
\end{tabular}

Extent of cooperation in price setting

Brueckner (2001) depends on governmental regulatory decisions. Captures competitive effects.
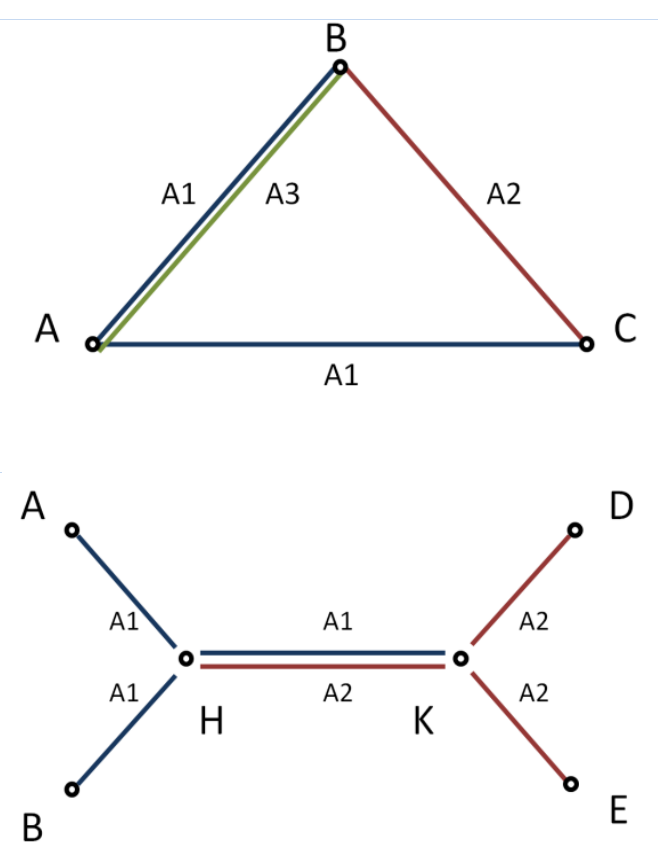

Table 1 (cont.) - Comparison of Network Models 


\section{Analysis of alternative results}

The effects of airline alliances on fares is investigated through several methodologies using different scenarios. (Zou et al. 2010) studied the effects on complementary alliances, which can be described as a link of two different airlines in which there wasn't competition on any segments of the pre-existing networks. In this case, it may be argued that the alliance may facilitate the elimination of double marginalization through cooperative price setting. Services for connecting passengers are normally improved by schedule coordination and more convenient connection. However it is found that passengers have a higher willingness to pay a premium for the enhanced services making the overall result in pricing have both positive and negative effects.

Park (1997) is also interested in studying the effects of complementary and parallel alliances on economic welfare. His model is very similar to (Zou et al. 2010) but includes a third airline as a competitor. In the complementary alliance, the competitor airline loses traffic to the alliance that provides a similar product. Competition due to the alliances in a specific market imposes positive externalities for the alliance partners in the other markets. The effects for the non-alliance firm are negative. Traffic gains for the alliance come mainly at the expense of the competitor airline. Overall, complementary alliances such as Northwest and KLM increase welfare while parallel alliance like Delta and Sabena tend to decrease consumer surplus.

The equilibrium analysis of codeshare alliances with a three node model considering three airlines performed by Chen (2006) shows that pricing incentives and competitive effects of a codesharing alliance depend on both the characteristics of the codesharing partners and the presence (or absence) of competition to become a partner. Foreclosing competition on an intermediate flight has a strong tendency to raise fares but if competition increases, airlines are forced to lower prices. Gayle (2006) found that close to half of the interline codeshare products are offered by operating carriers that simultaneously offer competing single-carrier products. In this case codesharing does not lead to marginal cost pricing for the intermediate

flight; i.e., double marginalization occurs. In the scenario where there is only a single potential codesharing partner for the intermediate flight, codesharing results in lower final 
prices for consumers, even when it does not eliminate double marginalization. This is an interesting result, showing that double marginalization does not necessarily mean a raise in prices.

In studying the economics of international codesharing Brueckner (2001) creates a six-node model with two airlines that have distinct networks except between hubs. This analysis of airline alliances also discusses the effects of anti-trust immunity on pricing. The model shows that forming an alliance, traffic is boosted and fares are reduced in all markets other than the interhub market. This is a similar result as that proved latter by Chen (2006) showing that the loss of competition causes fares to rise.

Brueckner (2003) presents another aspect of anti-trust immunity discussing that it allows collaboration in establishing fares. The extent of cooperation depends on governmental regulatory decisions. Typically the greater the cooperative relationship between airlines, the greater the benefits for consumers. Non-cooperative pricing in a Nash equilibrium leads to high fares and does not maximize joint profit. In this situation, each airline ignores the negative effect on the other airline's profit from an increase in its own subfare. Thus both lack of competition and lack of cooperation can be causes of higher fares when alliances are formed.

\section{Conclusion}

The purpose of this paper is to compare the existing literature regarding the theme of airline alliances particularly in international settings and prescribe the effects on airfares. The approach adopted is focused on theoretical modeling, qualitative factors involved and conclusions reached by the authors studied.

The main question this paper attempts to address is: what are the net effects of airline alliance formation on airfares? Different networks and scenarios may exist influencing the general aspects of competition prior to and after alliance formation. Airlines may or may not cooperate in setting prices for interline routes. These scenarios influence the net outcome of airline alliance formation. 
Despite differences in the approaches seen between the authors, findings aggregate to common conclusions. Traffic demand is shown to be stimulated due to enhanced services either by a reduction in fares or an improvement in service quality. Passengers may be willing to pay a premium for these enhanced services that may even cancel out the cost reductions obtained through synergies between the airlines. Cooperative price setting generate economic welfare while non-cooperative price setting may harm both passengers and airlines. Doublemarginalization could still create benefit of traffic demand stimulation and present decrease in fares if there wasn't competition on a determined route originally. Without exception, loss of competition leads to higher fares meaning that parallel alliances typically lead to loss of welfare. In summary, the overall result will be determined by the collaborative relationship between airlines within the alliance and the competitive landscape prior to the formation of alliance.

An interesting expansion upon the subject could include a study on the impact that an airline alliance between full service carriers has in the presence of low cost carriers and how pricing plays a role in market share evolution. The inclusion of a business model variable could greatly increase the understanding of this important phenomenon taking place in the airline industry.

\section{References}

Brueckner, J.K., (2001) The economics of international codesharing: an analysis of airline alliances. International Journal of Industrial Organization vol. 19, pp.1475-1498.

Brueckner, J.K., (2003) International airfares in the age of alliances: The effects of codesharing and antitrust immunity. Review of Economics and Statistics vol. 85, n.1, pp.105-118.

Chen, Y., Gayle, P.G., (2006) Vertical contracting between airlines: an equilibrium analysis of codeshre alliances. International Journal of Industrial Organization vol. 25, pp.1046-1060.

Park, J.H., (1997) The effects of airline alliances on markets and economic welfare. Tranportation research: Part E. Logistics and Transportation Review vol. 33, n. 3, pp.181-195

Wan, X., Zou, L., Dresner, M., (2009) Assessing the price effects of airline alliances on parallel routes. Transportation research: Part E. Logistics and Transportation Review vol. 45, n.4, pp.627-641.

Zou, L., Oum, T. H., Yu, C., (2010) 'Assessing the price effects of airline alliances on complementary routes', Transportation Reseatch Part E: Logistics and Tranportation Review vol. 47, n.3, pp.315-332. 